\section{John D. Millett}

John D. Millett, 81, president of Miami University, Oxford, Ohio, 1953-64; first chancellor of the Ohio Board of Regents 1964-72, and senior vice president of the Academy for Educational Development, Washington, D. C., 1972-80, died November 14, 1993, at Twin Towers Retirement Community, 5343 Hamilton Avenue, Cincinnati, where he and Mrs. Millett had made their home since shortly after his cardiac arrest in 1988. Funeral services in Oxford United Methodist Church, November 18, were followed by burial in Oxford Cemetery. Mrs. Millett remains at Twin Towers.

On return to Oxford as President Emeritus, Millett was a part-time Miami professor of educational leadership and adjunct professor of political science $1980-84$. He also was a consultant for several state governments and state universities and lectured on various campuses.

In his tenure as Miami's sixteenth president, its Oxford campus expanded from 5,100 students to nearly 9,000 , and enrollment at offcampus academic centers jumped from 1,000 to nearly 6,000 . Twentynine facilities costing about $\$ 30$ million were constructed. Academic developments included a common curriculum to broaden the university's liberal arts base; a new School of Applied Science, and new programs in paper technology, international studies and systems analysis.

It was in his administration that Miami became a pioneer in the branch campus development, a higher education trend that continued statewide through his years as chancellor. A major step came in 1964 when Miami and Ohio State combined their extension programs and with massive public support opened an entirely new joint branch campus. This became the separate Wright State University in 1967. Meanwhile, Miami campuses initiated by him and opened in Middletown in 1966 and Hamilton in 1968.

In resigning from Miami to accept appointment as chancellor, Millett also withdrew as part-time consultant to the U.S. Office of Education, where he had headed a task force establishing procedures for administering the Higher Education Facilities Act of 1963.

As first chancellor, Millett saw the number of Ohio's state universities expand from six to 12 and the number of two-year institutions, including university branches, grow from two to 50 .

His chancellorship bought development of an appropriation formula, the beginning of a permanent system for financing academic facilities, creation of a new medical school and expansion of medical schools at Ohio State and Cincinnati, the beginning of state support for the medical school at Case Western Reserve University, introduction of a student loan program, inauguration of construction loans for private colleges, expansion of operating support from $\$ 60$ million to $\$ 325$ million, and a capital improvement program of nearly $\$ 800$ million in state funds.

Considered an authority in public administration and the financing of higher education, he was author of 20 books, co-author of two, and contributor to 23 others. He became an international consultant and directed several major studies in his fields. He became president of the American Society for Public Administration 1960-61; chairman of its Committee on Standards for Instruction at the same time; president of the State Universities Association 1961-63, and chairman of the Ohio Commission on Education Beyond the High School 1962-63. He traveled extensively in Asia and Europe and was a consultant in the Philippines and Mexico. He also was on the national board for UNESCO.

\section{Miami University}

\section{William H. Riker}

William H. Riker, Professor Emeritus and formerly the Marie Curran Wilson and Joseph Chamberlain Wilson Professor of Political Science at the University of Rochester, died on June 26, 1993, of cancer. He was 72 .

Riker joined the faculty of the University of Rochester and was the chief moving force in establishing and building the Rochester program in political science, serving as the department chair from 1962 until 1979. In particular, his efforts were devoted to creating a graduate program with a special profile that would develop a new subfield in which formal theory and modelling techniques adapted from economics would be applied to the processes of politics. He was also concerned to apply rigorous quantitative techniques in the testing of theories, requiring all graduate students to complete a mathematics and statistics sequence and making available advanced methods courses. The program is now regularly ranked in the top handful in the country. The field of formal or positive theory has been established in departments across the land from Harvard to Caltech, often with Rikertrained $\mathrm{Ph}$.Ds. from Rochester or their students, and the quantitative training has been widely adopted.

Riker graduated from Depauw University and received his doctorate from Harvard. Before coming to Rochester he taught for 14 years at Lawrence University in Wisconsin. His many publications include several books that have become classics. These include Democracy in the United States (1953 and 1965), The Theory of Political Coalitions (1962), Federalism: Origin, Operation, Maintenance (1964), Introduction to Positive Political Theory, with former student Peter Ordeshook, (1973), Liberalism against Populism (1982), and The Art of Political Manipulation (1986). He published over a dozen articles in the American Political Science Review, as well as numerous contributions to the other leading journals of our profession. A man of wide-ranging interests, he contributed not only to political science journals, but to such publications as Scientific American, Journal of Philosophy, Journal of the History of Ideas, and Journal of American Folklore, the last a numerological analysis of the song, "The Twelve Days of Christmas."

Many of Riker's works exemplified the application of formal theory and modeling techniques to political problems, especially to issues 
of coalition formation and agenda manipulation. Among the best known, in addition to The Theory of Political Coalitions and Liberalism against Populism, are his papers "Implications from the Disequilibrium of Majority Rule for the Study of Institutions" (APSR 1980 ), which raised a fundamental question about how we understand the stability of institutions; "A Theory of the Calculus of Voting" (APSR 1968, with P. Ordeshook), on the motivations for rational participation; "Bargaining in ThreePerson Games" (APSR 1967), one of the first efforts at experimental testing of rational choice models in political science; and “Arrow's Theorem and Some Examples of the Paradox of Voting" (in Claunch, ed., Mathematical Applications in Political Science I, 1965), exhibiting legislative manifestations of majority voting cycles. These works have encouraged and shaped several generations of scholarship in formal theory.

While the path-breaking work by Riker and his students in formal theory will no doubt remain his most remarkable contribution, Bill Riker was deeply interested in empirical and normative scholarship as well. From his early detailed case studies of decision making by the National Labor Relations Board, through his work on federalism, Congressional roll-call voting, railroad abandonment and air transport deregulation, to the studies of the ratification of the American Constitution that occupied much of his time during the last decade, Bill Riker was fascinated by the events of politics and used his formidable analytic powers to explain them. The charming series of applications of rational choice analysis to historic (and even fictitious) events in The Art of Political Manipulation represent Bill Riker's wide-ranging empirical interests in a vein intended to amuse as well as instruct. Moreover, he seldom neglected for long the great normative issues of democracy and (as in Liberalism Against Populism) continually pressed to understand how our growing knowledge of the nature of social choice shaped our very formulation of these issues.
During the course of his lengthy career, he received many honors. He was elected to the American Academy of Arts and Sciences and to the National Academy of Sciences; he served as president of the American Political Science Association in 1982-83; he co-founded the Public Choice Society, and served as its president from 1965 to 1967. A Guggenheim Fellow, he received honorary degrees from Lawrence University, Depauw University, SUNY Stony Brook, and the University of Uppsala in Sweden. A vital and inspiring teacher, he received three awards for teaching, the Uihlein Prize at Lawrence University, and the Edward Peck Curtis Awards both for undergraduate and for graduate teaching at the University of Rochester. He also served as Rochester's University Dean of Graduate Studies and as a member of the City of Rochester zoning board.

Although he retired in a technical sense in 1991, Riker continued to teach and to do research full time. At the time of his death, a book he had edited, Agenda Formation, had just been published, and he had completed a book manuscript, Rhetorical Interaction in the Ratification Campaign. He was also deeply involved in a project investigating the creation and protection of property rights, with special emphasis on developments in East Europe and the former Soviet Union. He was planning, and looking forward with characteristic relish, to spending part of the summer in South Korea, where he had been invited to advise the government on the subject of federalism.

In his colleagues' eyes, however, Bill Riker's considerable skills as an institution-builder, teacher, and social scientist could never overshadow his qualities as a colleague and mentor. His energy and enthusiasm were infectious; his commitment to political science exemplary; and his store of knowledge aweinspiring. He had time for every colleague and every student, and a knack for the encouraging word that continually spurred us on. Bill's influence on each of us, like his influence on the department and the discipline, will prove longlasting.

Survivors include his wife, Mary Elizabeth Riker of Rochester; a son, William H. Riker, Jr., of Providence, Rhode Island; two daughters, Katharine Riker of Portland, Oregon, and Mary Paris Riker, of Chico, California; and three grandchildren. Another son, Benjamin, predeceased him.

Memorial contributions may be made to the William H. Riker Fund at the Department of Political Science, University of Rochester. An effort is presently under way to create an annual William H. Riker Memorial Prize and Lecture to recognize outstanding achievements in the study of politics; contributions to the Riker Fund will be used toward endowing this prize.

Randall Calvert

John Mueller

G. Bingham Powell

University of Rochester

\section{Arthur Bruce Winter}

Arthur Bruce Winter, Professor Emeritus, Political Science Department, University of Nebraska-Lincoln, died at home in Lincoln, Nebraska on October 6, 1993. He was 75 years old and had been retired for five years.

Born in Mount Vernon, New York, Bruce was on active duty with the U.S. Navy on December 7, 1941. He served for the duration of World War II, having been commissioned as an officer in 1944. After separation from the service, he remained active in the Naval Reserve.

He received a BA in Political Science from Emory University in 1946 and an MS in Government Management from the University of Denver in 1948. His PhD, awarded in 1955, was from Duke University. Bruce began his career as a research associate in the Bureau of Public Administration at the University of Tennessee. In 1954, he accepted a position with the University of Nebraska and remained with the department until his retirement in 1989.

For twenty years, he was direc- 